\title{
Multiple Sclerosis: Enzymatic Cross Site-Specific Hydrolysis of H1 Histone by IgGs against H1, H2A, H2B, H3, H4 Histones, and Myelin Basic Protein
}

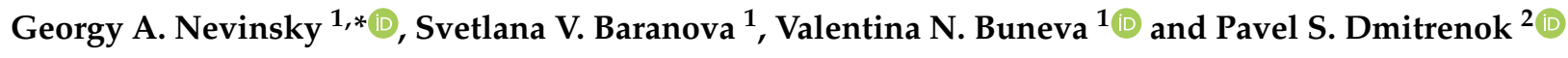 \\ 1 Siberian Division, Institute of Chemical Biology and Fundamental Medicine, Russian Academy of Sciences, \\ Lavrentiev Ave. 8, 630090 Novosibirsk, Russia; swb@ngs.ru (S.V.B.); buneva@niboch.nsc.ru (V.N.B.) \\ 2 Far East Division, Pacific Institute of Bioorganic Chemistry, Russian Academy of Sciences, \\ 690022 Vladivostok, Russia; paveldmt@piboc.dvo.ru \\ * Correspondence: nevinsky@niboch.nsc.ru
}

check for updates

Citation: Nevinsky, G.A.; Baranova, S.V.; Buneva, V.N.; Dmitrenok, P.S. Multiple Sclerosis: Enzymatic Cross Site-Specific Hydrolysis of $\mathrm{H} 1$ Histone by IgGs against H1, H2A, H2B, H3, H4 Histones, and Myelin Basic Protein. Biomolecules 2021, 11, 1140. https://doi.org/10.3390/ biom 11081140

Academic Editor: Koen

Vandenbroeck

Received: 7 July 2021

Accepted: 29 July 2021

Published: 2 August 2021

Publisher's Note: MDPI stays neutral with regard to jurisdictional claims in published maps and institutional affiliations.

Copyright: (c) 2021 by the authors. Licensee MDPI, Basel, Switzerland. This article is an open access article distributed under the terms and conditions of the Creative Commons Attribution (CC BY) license (https:// creativecommons.org/licenses/by/ $4.0 /)$.

\begin{abstract}
Histones play a key role in chromatin remodeling and gene transcription. Further, free histones in the blood act as damage-associated molecules. Administration of histones to animals results in systemic inflammatory and toxic effects. Myelin basic protein is the principal constituent element of the myelin-proteolipid sheath of axons. Abzymes (antibodies with catalytic activities) are the original features of some autoimmune diseases. In this study, electrophoretically homogeneous IgGs against $\mathrm{H} 1, \mathrm{H} 2 \mathrm{~A}, \mathrm{H} 2 \mathrm{~B}, \mathrm{H} 3$, and $\mathrm{H} 4$ histones and myelin basic protein (MBP) were isolated from the blood sera of multiple sclerosis (MS) patients by several affinity chromatographies. Using MALDI mass spectrometry, the sites of $\mathrm{H} 1$ histone cleavage by IgGs against H1, H2A, H2B, H3, $\mathrm{H} 4$, and MBP were determined. It was shown that IgGs against $\mathrm{H} 1$ split $\mathrm{H} 1$ at 12 sites, while the number of cleavage sites by abzymes against other histones was lower: H2A (9), H2B (7), H3 (3), and $\mathrm{H} 4$ (3). The minimum rate of $\mathrm{H} 1$ hydrolysis was observed for antibodies against $\mathrm{H} 3$ and $\mathrm{H} 4$. A high rate of hydrolysis and the maximum number of $\mathrm{H} 1$ hydrolysis sites (17) were found for antibodies against MBP. Only a few sites of $\mathrm{H} 1$ hydrolysis by anti-H1 antibodies coincided with those for IgGs against H2A, H2B, H3, H4, and MBP. Thus, the polyreactivity of complexation and the enzymatic cross-activity of antibodies against $\mathrm{H1}$, four other histones, and MBP have first been shown. Since histones act as damage molecules, abzymes against histones and MBP can play a negative role in the pathogenesis of MS and probably other different diseases as well.
\end{abstract}

Keywords: human blood sera antibodies; multiple sclerosis patients; catalytic antibodies-abzymes; hydrolysis of H1 histone; IgGs against H1; H2A; H2B; H3; H4 histones; myelin basic protein

\section{Introduction}

Antibodies (Abs) against stable analogs of reaction transition states and natural autoantibodies with enzymatic activities are known as "abzymes," and they are decently described in the literature [1-6]. The spontaneous and antigen-accelerated development of autoimmune diseases (AIDs) leads to the production of auto-antibodies-abzymes (ABZs) against lipids, polysaccharides, peptides, proteins, DNAs and RNAs, and their complexes. In the blood sera of autoimmune disease patients, many different ABZs directly against various antigens mimicking transition states of chemical reactions have been found. Secondary anti-idiotypic auto-ABZs to active sites of canonical enzymes have also been found, whose forms may be explained by Erne's model of the anti-idiotypic network [7]. The appearance of ABZs in the blood is a very clear sign of the occurrence of autoimmune processes in humans and mammals [1-6]. To date, IgGs or IgMs, and IgAs splitting DNAs, RNAs [8-12], oligosaccharides [13-15], oligopeptides, and proteins [16-23] have been found in the blood of patients with autoimmune and various viral diseases [1-6]. 
Some healthy humans and mammals produce ABZs with low vasoactive intestinal peptide- [16], thyroglobulin- [18], and polysaccharide-hydrolyzing [13-15] activities, but usually, healthy humans and patients with some diseases characterizing insignificant autoimmune reactions lack abzymes [1-6]. Nonetheless, germline antibodies of healthy humans could demonstrate amyloid-directed and superantigen-directed enzymatic activities [24,25].

MBP is the main component of the myelin-proteolipid sheath of axons. The proteinspecific abzymes against MBP can attack and hydrolyze the MBP of the myelin sheath of axons, playing a very negatory role in MS pathogenesis due to their disrupting of nerve impulse conduction. [1-6,21,22]. Histones and their different post-translational forms bear a vital role in the functioning and remodeling of chromatin. Free extracellular histones act as damage molecules, causing systemic toxic effects through inflammatory pathways and the activation of Toll-like receptors [26]. Abzymes that hydrolyze MBP and five histones have been detected in the blood of HIV-infected [21,22,27-34], SLE [35], and MS [36] patients, and in mice with experimental encephalomyelitis [37]. In autoimmune diseases patients, many anti-DNA and anti-histones Abs are directed against histone-DNA complexes appearing in the blood due to internucleosomal cleavage during apoptosis [38]. The existence of enzymatic cross-reactivity of ABZs against MBP and histones is dangerous to humans because histones, caused by cell apoptosis, occur constantly in human blood. Considering this, the analysis of the possible catalytic cross-reactivity of antibodies against $\mathrm{MBP}$ and histones is very important.

The unspecific complexation of some antigens with antibodies against foreign ligands is a widely distributed phenomenon [39-42]. Specific for various substrates, classic enzymes usually catalyze only one chemical reaction [43-45]. All described to date ABZs against different proteins could usually split only their specific proteins [1-6]. The first examples of catalytic cross-reactivity were anti-MBP IgGs and antibodies against H1, H2A, $\mathrm{H} 2 \mathrm{~B}, \mathrm{H3}$, and $\mathrm{H} 4$ histones from the sera of HIV-infected patients [32-34]. At the same time, an analysis of the possible polyreactivity of complexation and catalytic cross-reactivity of antibodies against the five histones themselves has not yet been carried out. We have suggested that if antibodies against $\mathrm{H} 1, \mathrm{H} 2 \mathrm{~A}, \mathrm{H} 2 \mathrm{~B}, \mathrm{H} 3$, and $\mathrm{H} 4$ histones have enzymatic cross-reactivity with antibodies against MBP, then they potentially can hydrolyze not only their specific histone but other histones as well.

In this work, an analysis of the ability of the antibodies of MS patients against H1, $\mathrm{H} 2 \mathrm{~A}, \mathrm{H} 2 \mathrm{~B}, \mathrm{H} 3$, and $\mathrm{H} 4$ histones and MBP to hydrolyze $\mathrm{H} 1$ histone was performed for the first time. It was shown that not only abzymes against these proteins of HIV-infected patients [32-34], but also those of patients with multiple sclerosis, have catalytic crossreactivity. Moreover, it was also shown that abzymes against all five histones are capable of hydrolyzing histone $\mathrm{H} 1$ with different efficiency and in different sites.

\section{Material and Methods}

\subsection{Chemicals, Donors, and Patients}

All chemicals used, including five homogeneous human histones and an equimolar mixture of five histones (H1, H2A, H2B, H3, and H4), were from Sigma (St. Louis, MO, USA). Superdex 200 HR 10/30 and Protein G-Sepharose columns were obtained from GE Healthcare (GE Healthcare, New York, NY, USA). Human MBP was perched from the Molecular Diagnostics and Therapy Center of DBRC (Moscow, Russia). Histone- and MBP-Sepharose columns were prepared according to the manufacturer's protocol using BrCN-activated Sepharose (Sigma), MBP, five individual histones, or their mixtures.

Evidence that multiple sclerosis patients hydrolyze five histones and MBP has been previously published using IgGs from the blood of 59 patients [21,22,31]. Patient data are given in Supplementary Table S1. The diagnosis of multiple sclerosis was established according to the classification of McDonald [46] by specialists from the multiple sclerosis center (Novosibirsk Medical University). Disease severity of all 59 MS patients was scored using Kurtzke's Expanded Disability Status Scale (EDSS) [47]. The patients at entry had no 
symptoms of any infections. None of the MS patients at the time of sample collection had received any anti-disease therapies during the 6 months before the study.

The protocol of blood sampling was confirmed by the local human ethics committee (Novosibirsk State Medical University, Novosibirsk, Russia; number 105-HIV; 07. 2010). This ethics committee supported this study based on the guidelines of the Helsinki ethics committee. All patients made a written agreement to donate blood for scientific purposes.

In this work, we used an equimolar mixture of 15 of the 59 IgGs described earlier [31] with high activity in the hydrolysis of five histones and MBP.

\subsection{Antibody Purification}

Electrophoretically homogeneous preparations of IgGs were obtained from the blood of MS patients by sequential affinity chromatography of the blood serum proteins, first on Protein G-Sepharose and additionally by gel filtration on a Superdex 200 HR 10/30 column, as in [31-34]. To protect IgG preparations from bacterial and viral contamination, they were filtered through a Millex filter (pore size $0.1 \mu \mathrm{M}$ ). After 6-7 days of storage at $4{ }^{\circ} \mathrm{C}$ for refolding, the IgGs were used in different assays. SDS-PAGE analysis of Abs for homogeneity was carried out in $4-17 \%$ gradient gels ( $0.1 \%$ SDS), and proteins were visualized by silver staining, as in [31-34].

Earlier, using eluates of 3-4-mm cross-sections of the gel longitudinal slices after SDS-PAGE of antibodies, it has been shown that IgGs of MS patients do not contain any canonical protease impurities [31]. Protease activity was found only in the eluates of the gel fragments corresponding to IgGs.

\subsection{Affinity Chromatography of IgGs on MBP- and Histones-Sepharose}

To isolate antibodies against various histones, we used a mixture of $15 \mathrm{Abs}\left(\operatorname{IgG}_{\mathrm{mix}}\right)$ that exhibit high activity in the hydrolysis of histones and MBP [31]. Removal of all Abs against five histones from homogeneous polyclonal $\mathrm{IgG}_{\text {mix }}$ having no impurities of any canonical proteases was carried out using MBP-Sepharose bearing immobilized MBP, equilibrated in buffer A ( $20 \mathrm{mM}$ Tris- $\mathrm{HCl}, \mathrm{pH}$ 7.5). After IgGs loading, to obtain the fraction containing IgGs against MBP, the column was washed to zero optical density $\left(\mathrm{A}_{280}\right)$ with buffer A. Adsorbed IgGs against MBP were eluted using buffer A containing $\mathrm{NaCl}(0.2 \mathrm{M})$, and finally were specifically eluted by $3.0 \mathrm{M} \mathrm{NaCl}$ and $0.1 \mathrm{M}$ glycine- $\mathrm{HCl}, \mathrm{pH} 2.6$. The fractions eluted from MBP-Sepharose with $3.0 \mathrm{M}$ and acid buffer were used for additional purification from potentially possible impurities of IgGs against 5 histones. They were applied on the column of histone5-Sepharose (immobilized mixture of 5 histones). The fraction of Abs eluted upon the loading was named and used as anti-MBP IgGs.

The fraction eluted from MBP-Sepharose at loading (containing a mixture of IgGs against 5 histones) was used for purification of the IgGs against five individual histones using coherently Sepharose-containing immobilized H1 (H1-Sepharose), H2A (H2ASepharose), H3 (H3-Sepharose), and H4 (H4-Sepharose) histones. Antibodies with no affinity for the previous sorbent were applied to the next sorbent. All chromatographies were performed as in the case of MBP- and histone5-Sepharose. IgGs against H1-H4 histones were specifically eluted with buffer $(\mathrm{pH}$ 2.6). These fractions were named anti-H1, anti-H2A, anti-H2B, anti-H4, and anti-H4 IgGs, respectively.

\subsection{Proteolytic Activity Assay}

The reaction mixtures (10-15 $\mu \mathrm{L}$ ) contained $20 \mathrm{mM}$ Tris- $\mathrm{HCl}(\mathrm{pH} 7.5), 0.7 \mathrm{mg} / \mathrm{mL} \mathrm{H1}$ histone or $1.0 \mathrm{mg} / \mathrm{mL}$ MBP, and $0.01-0.1 \mathrm{mg} / \mathrm{mL}$ IgGs against one of five histones, $\mathrm{H} 1-\mathrm{H} 4$, or MBP. The mixtures were incubated for $1-24 \mathrm{~h}$ at $37^{\circ} \mathrm{C}$. The efficiency of histone H1 and MBP splitting was analyzed by standard SDS-PAGE using 15\% gels under nonreducing conditions (in the absence of DTT), as in [27-35]. The products of H1 and MBP hydrolysis were revealed using Coomassie Blue. The gels after painting were scanned and quantified using Image Quant v5.2 software, as in [31]. The efficiency of protein hydrolysis was 
assessed by their decrease in comparison with the control-incubation of the proteins in the absence of antibodies.

\subsection{MALDI-TOF Analysis of Abs-Dependent H1 Histone Hydrolysis}

$\mathrm{H} 1$ hydrolysis by IgGs against five histones (H1-H4) was performed using MALDI analysis. The analysis was carried out using the Reflex III system from Bruker Company (Frankfurt, Germany): 337-nm nitrogen laser VSL-337 ND, 3 ns pulse duration. Mixtures $(10 \mu \mathrm{L})$ containing $20 \mathrm{mM}$ Tris- $\mathrm{HCl}(\mathrm{pH} 7.5), 0.7 \mathrm{mg} / \mathrm{mL}$ one of histones and $0.04 \mathrm{mg} / \mathrm{mL}$ one of IgG preparation were incubated during $0-24 \mathrm{~h}$. To $1.2 \mu \mathrm{L}$ of the sinapinic acid matrix mixed with $1.2 \mu \mathrm{L}$ of $0.2 \%$ trifluoroacetic acid, $1.2 \mu \mathrm{L}$ of the solutions containing $\mathrm{H} 1$ before or after incubation with various IgGs were added; $1-1.2 \mu \mathrm{L}$ of these mixtures were applied on the MALDI plates, which then were air-dried. Calibrations of all MALDI spectra were performed using standard protein mixtures II and I (Germany, Bruker Daltonic) in the internal and/or external calibration modes. The analysis of peptide MMs corresponding to specific sites of H1 hydrolysis by different IgGs was performed using Protein Calculator v3.3 (Scripps Research Institute; La Jolla, CA, USA).

\subsection{Analysis of Sequence Homology}

The analysis of homology between histones and MBP sequences was carried out using lalign (http: / / www.ch.embnet.org/software/LALIGN_form.html) (accessed on Internet).

\subsection{Statistical Analysis}

The results are given as mean \pm S.D. of 7-10 independent MALDI specters for each sample of the different IgGs.

\section{Results}

\subsection{Purification of Antibodies}

In this work, we used previously described electrophoretically homogeneous polyclonal IgGs from the sera of 15 MS patients isolated by sequential chromatography of the serum proteins, first on Protein G-Sepharose in conditions allowing for the removal of nonspecifically bound proteins [31-34]. Then, IgGs were subjected to FPLC gel filtration under rigid conditions ( $\mathrm{pH}$ 2.6), destroying immune complexes according to [31-34]. To analyze the "average" site-specific hydrolysis of H1 histone by IgGs against five histones (H1-H4), we prepared a mixture of equal amounts of $15 \mathrm{IgGs}\left(\operatorname{Ig} \mathrm{G}_{\mathrm{mix}}\right)$, which demonstrated high activities in the splitting of $\mathrm{H} 1$ histone and MBP. Any possible artifacts due to traces of contaminating canonical proteases were excluded earlier [31]; the $\operatorname{IgG}_{\text {mix }}$ was separated by SDS-PAGE, and its histone- and MBP-hydrolyzing activities were detected in only one protein band corresponding to $\operatorname{IgG}_{\text {mix }}$. Then, we isolated $\operatorname{IgG}$ s against MBP by $\operatorname{IgG}_{\text {mix }}$ affinity chromatography on MBP-Sepharose. IgGs nonspecifically bound to the sorbent were first eluted with $0.2 \mathrm{M} \mathrm{NaCl}$. Specific IgGs against MBP were eluted with $3.0 \mathrm{M} \mathrm{NaCl}$ and acidic buffer ( $\mathrm{pH}$ 2.6). For additional purification from potential impurities against five histones, a mixture of these IgG fractions was passed through histone5-Sepharose. The fraction released upon loading onto the column was further used as anti-MBP IgGs.

The fraction eluted from MBP-Sepharose on loading was used to isolate IgGs against five individual histones. This fraction was passed once more through MBP-Sepharose and then used to isolate antibodies against five individual histones. For this, it was applied sequentially to five sorbents with immobilized $\mathrm{H} 1, \mathrm{H} 2 \mathrm{~A}, \mathrm{H} 2 \mathrm{~B}, \mathrm{H} 3$, and $\mathrm{H} 4$ histones. Fractions without affinity for the previous sorbent, eluted upon loading, were used for each subsequent chromatography. Finally, we obtained five preparations of antibodies against five individual histones: anti-H1, anti-H2A, anti-H2B, anti-H3, and anti-H4 IgGs.

\subsection{SDS-PAGE Analysis of Histones and MBP Hydrolysis}

As shown earlier, polyclonal antibodies from the blood of HIV-infected patients [27-30] and patients with MS effectively hydrolyze both five histones [31] and MBP [21,22]. More- 
over, antibodies from the blood of HIV-infected patients against five histones and MBP possess not only the ability of polyspecific complexation but are also capable of efficiently cross-reactively hydrolyzing both five histones and MBP [31-34]. An interesting question was whether IgGs from the blood of MS patients against histones are also capable of hydrolyzing both five histones and MBP, and vice versa. To analyze this kind of catalytic cross-reactivity, we used the total fraction of anti-histone IgGs (specifically eluted from histone5-Sepharose) and anti-MBP antibodies (specifically eluted from MBP-Sepharose). As can be seen from Figure 1A, anti-histone and anti-MBP IgG hydrolyze all five histones with comparable efficiency. The MMs of $\mathrm{H} 3$ and $\mathrm{H} 2 \mathrm{~A}$ and their electrophoretic mobility are so close that they cannot be separated efficiently (Figure 1A). Therefore, to confirm that the hydrolysis of $\mathrm{H} 3$ is more reliable, we performed homogeneous $\mathrm{H} 3$ histone hydrolysis using the total fraction of anti-histone IgGs (Figure 1C).

A

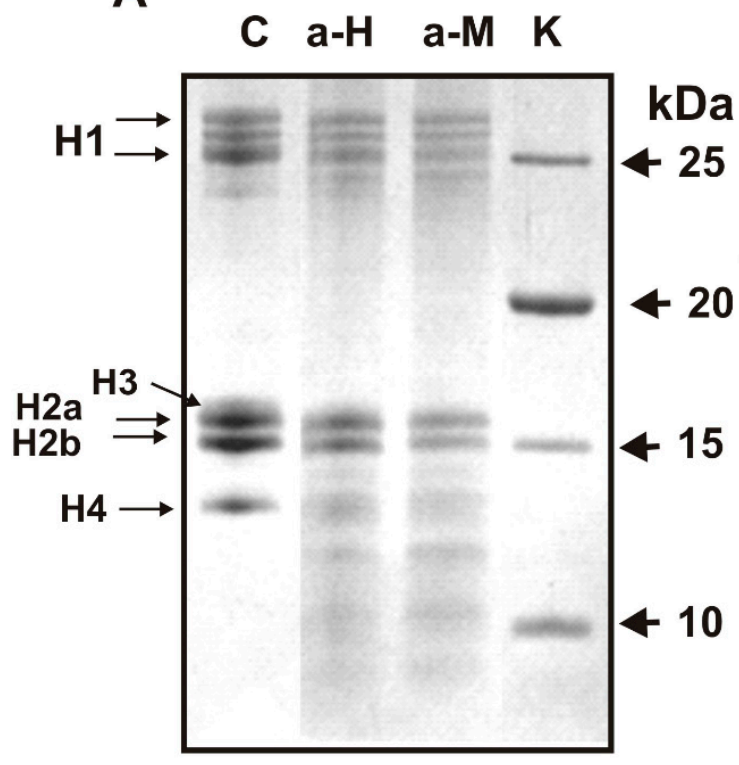

B

C

\section{C a-H a-M K kDa}

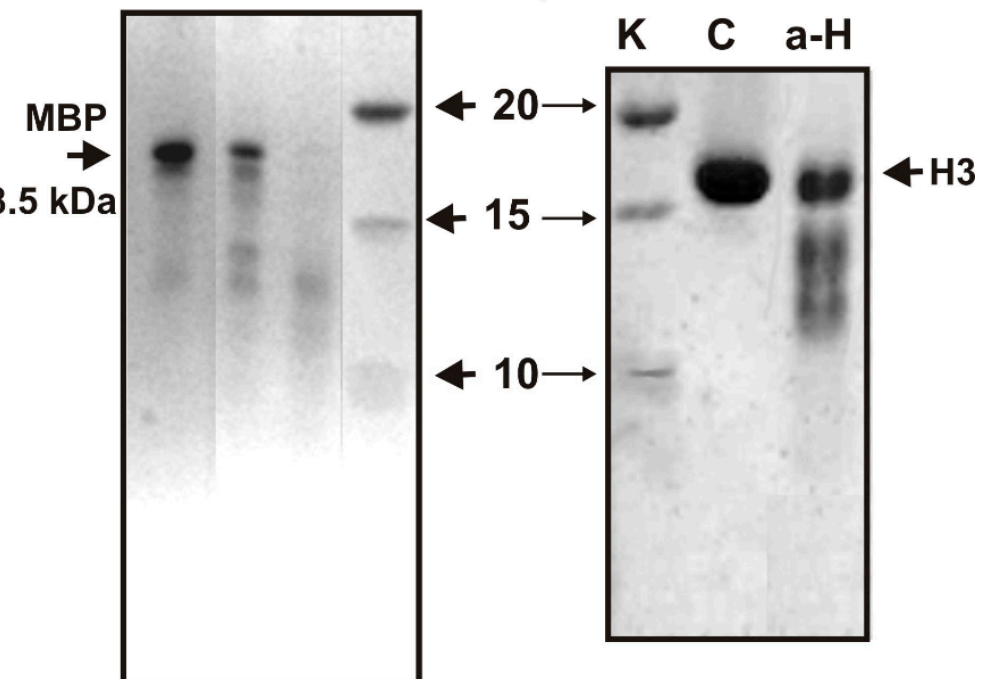

Figure 1. SDS-PAGE analysis of five H1-H4 histones hydrolysis by IgGs against five histones (lane a-H) and MBP (lane a-M) (A) as well as MBP by anti-histones (lane a-H) and anti-MBP IgGs (lane a-M) (B). Hydrolysis of homogeneous H3 histone by IgGs against five histones (C). Lane C correspond to hive histones (A), and MBP (B) and homogeneous H3 (C) incubated in the absence of IgGs. Lane K corresponded to proteins with known molecular masses (A-C). Five histones, MBP and homogeneous $\mathrm{H} 3$ in the absence and in the presence of $\mathrm{IgGs}(0.03 \mathrm{mg} / \mathrm{mL})$ were incubated for $10 \mathrm{~h}$.

Electrophoretically homogeneous preparations of human MBP, unfortunately, were not available. Due to cDNA alternative splicing and different partial MBP hydrolysis in the brains of various humans, these protein preparations could contain several related forms $(18.5,17.5$, and $\leq 14.0 \mathrm{kDa})$ and products of their hydrolysis [21,22]. Figure 1B demonstrates MBP hydrolysis by anti-MBP and anti-histone IgG preparations. Line $\mathrm{C}$ of Figure 1B demonstrates the starting MBP preparation heterogeneity containing mainly $18.5 \mathrm{kDa}$ protein forms. After $10 \mathrm{~h}$ of incubation with both IgG preparations, all MBP forms decreased remarkably compared to the control (lane C). These data may potentially indicate that IgGs against histones and MBP from the sera of MS patients could possess a known phenomenon of polyreactivity in complex formation [39-42] and mutual catalytic cross-reactivity in MBP- and histone hydrolysis. These data, however, do not provide absolute evidence of catalytic cross-reactivity between IgGs against five histones and MBP because, in spite of their purifications by several affinity chromatographies, it cannot be ruled out that the IgGs obtained nevertheless potentially could contain small impurities of alternative Abs. The best evidence of cross-catalytic activities may be obtained from an obvious difference in the specific sites of the hydrolysis of histones by IgGs against these five histones and against MBP. However, the main objective of this study was not 
only to analyze the possibility of cross-catalyzing the hydrolysis of histones and MBP by antibodies against these proteins, but for the first time to investigate, using the example of antibodies from MS patients, whether there is cross-catalytic activity of antibodies against five histones. In this work, we analyzed the possibility of the hydrolysis of histone $\mathrm{H} 1$ with specific Abs against five histones (H1-H4) and MBP.

\subsection{MALDI Analysis of H1 Histone Hydrolysis}

The IgG fractions with high affinity to five individual histones and to MBP were used to reveal the cleavage sites of histone $\mathrm{H} 1$ by MALDI TOFF mass spectrometry. After the addition of these IgGs (Figure 2A), H1 histone was nearly homogeneous: there were only two signals of its one- $(m / z=20719.2 \mathrm{Da})$ and two-charged ions $(m / z=10359.6 \mathrm{Da})$.

\section{Hydrolys of $\mathrm{H} 1$ histone by IgGs against different histones}

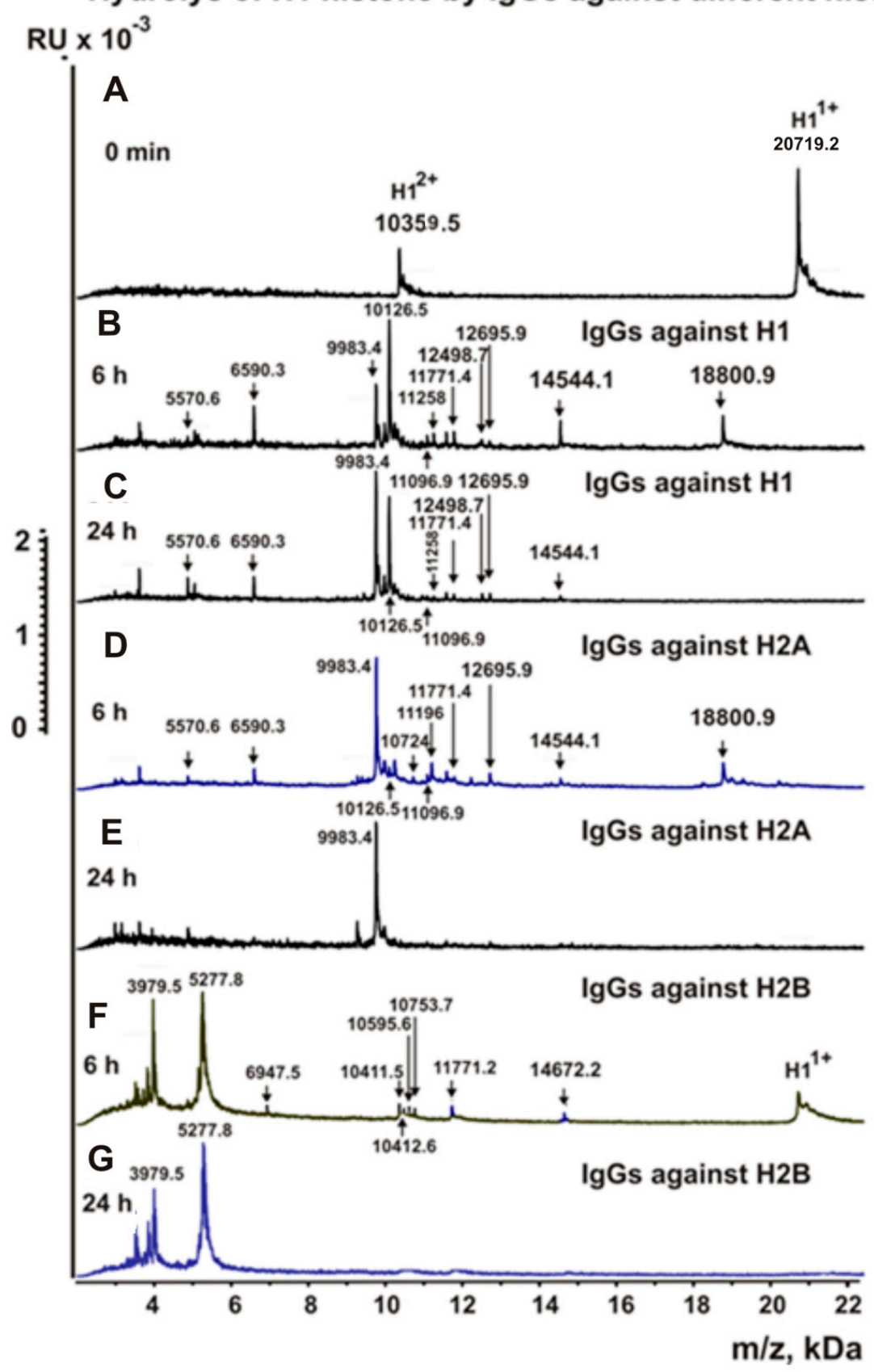

Figure 2. MALDI spectra (A-G) corresponding to hydrolysis of $\mathrm{H} 1 \mathrm{histone}(0.7 \mathrm{mg} / \mathrm{mL})$ over time $(0-24 \mathrm{~h})$ in the presence of IgGs $(0.04 \mathrm{mg} / \mathrm{mL})$ against H1 $(\mathbf{B}, \mathbf{C}), \mathrm{H} 2 \mathrm{~A}(\mathbf{D}, \mathbf{E})$, and H2B $(\mathbf{F}, \mathbf{G})$. 
H1 hydrolysis assays were performed with IgGs against five histones and MBP after 3, 6 , and $24 \mathrm{~h}$ of incubation. Almost all the main peaks corresponding to different sites of $\mathrm{H} 1$ hydrolysis by IgGs against H1 histone are clearly visible after 6 h of hydrolysis (Figure 2B). Incubation of mixtures for $24 \mathrm{~h}$ led to complete hydrolysis of initial $\mathrm{H} 1$ and the formation of its different fragments (Figure 2C). Based on the analysis of peaks in 10 spectra, 13 sites of the hydrolysis were identified, three of which are major (L94-A95, K131-A132, and K135K136), six moderate (A88-S89, R93-L94, K96-S97, P100-K101, S103-V104, and T109-K110), and four minor splitting sites (V75-T76, A117-T118, A128-A129, and P141-V142).

The H1 hydrolysis assay with anti-histone H2A antibodies was carried out in a similar manner to the splitting of H1 with anti-H1 IgGs. Figure 2D,E show MALDI spectra of the products of the reaction mixture after hydrolysis of $\mathrm{H} 1$ histone with anti-H2A IgGs for 6 and $24 \mathrm{~h}$. These antibodies effectively cleave $\mathrm{H} 1$ to very small peptides in $24 \mathrm{~h}(<5 \mathrm{kDa})$ with the formation of only one more stable product observed (9983.4 Da; Figure 2E). Based on the analysis of 10 spectra, 9 hydrolysis sites were reliably detected: one major (V104-A105), five moderate (R93-L94, L94-A95, A117-T118, K127-A128, and A132-P133), and three minor (R46- Q47, S103-V104, T109-K110) sites.

Anti-H2B histone antibodies hydrolyzed $\mathrm{H} 1$ with approximately the same efficiency as anti-H1 and anti-H2A antibodies, and after $24 \mathrm{~h}$ of incubation, no peak of initial histone $\mathrm{H} 1$ was found (Figure 2F,G). Interestingly, in this case of H1 hydrolysis by anti-H2B antibodies, other sites in comparison with those for anti-H1 and anti-H2A antibodies were mainly found. Seven reliably detectable hydrolysis sites were found, among which one was major (A156-K157) and six were minor sites (Q82-T83, R93-L94, S97-D98, P100-K101, K127-A128, K136-P137) (Figure 2F).

Antibodies against histone $\mathrm{H} 3$ also cleaved $\mathrm{H} 1$, but at a rate approximately 7-10-fold lower than that of the anti-H1, anti-H2A, and anti-H2B abzymes (Figure 3A,B). After $6 \mathrm{~h}$ of incubation, only one detectable product of the hydrolysis was detected (Figure 3A). After 24 incubation, two additional reliably tested products of histone splitting appeared.

Based on the totality of 10 spectra, only three H1 cleavage sites by anti-histone H3 antibodies were found. One of the sites should be considered as major (A145-K146), one moderate (A156-K157), and one minor (F106-K107).

The abzymes against histone H4 hydrolyzed H1 very slowly. Only after $24 \mathrm{~h}$ of incubation were several significant peaks of $\mathrm{H} 1$ hydrolysis by these antibodies found (Figure 3C,D). Ultimately, three reliably tested sites for hydrolysis of H1 by anti-H4 antibodies were identified. Two sites were classified mostly as minor sites (K127-A128, and K136-P137) and only T109-K110, the peak corresponding to which appears first, can be classified as a moderate hydrolysis site.

It should be noted that anti-MBP antibodies efficiently hydrolyze all five histones (Figure 1A). Figure 3B,D show the spectra of the products of H1 hydrolysis by antibodies against MBP for 3 and $6 \mathrm{~h}$ of hydrolysis. It can be seen that, especially after $6 \mathrm{~h}$, a large number of histone $\mathrm{H} 1$ hydrolysis products were formed. The anti-MBP abzymes hydrolyzed $\mathrm{H} 1$ very efficiently. After $6 \mathrm{~h}$ of incubation, 17 reliable sites of $\mathrm{H} 1$ hydrolysis were found. Four of them were major (16K-17A, V104-A105, F106-K107, and E112-I113), two were moderate (14R-15A, K107-K108) and 11 were minor, but the reliably tested sites were the following: P12-K13, K19- K20, K20-S21, S21-T22, P100-K101, K108-T109, K115-V116, V116-A117, A117-T118, K120-K121, and K131-A132.

Figure 4 summarizes the data on the sites of $\mathrm{H} 1$ hydrolysis by antibodies against all 5 histones and MBP. Major hydrolysis sites are indicated by stars $(\star)$, moderate by an arrow $(\downarrow)$, and minor by colons (:).

As can be seen from Figure 4, antibodies against five histones and MBP strongly differ in the number, cleavage efficiency, and position of hydrolysis sites in the histone $\mathrm{H} 1$ protein sequence. To simplify the analysis of the overlapping and different hydrolysis sites of the six antibody preparations, all data are collected in Table 1. 
Hydrolys of $\mathrm{H} 1$ histone by IgGs against different histones and MBP

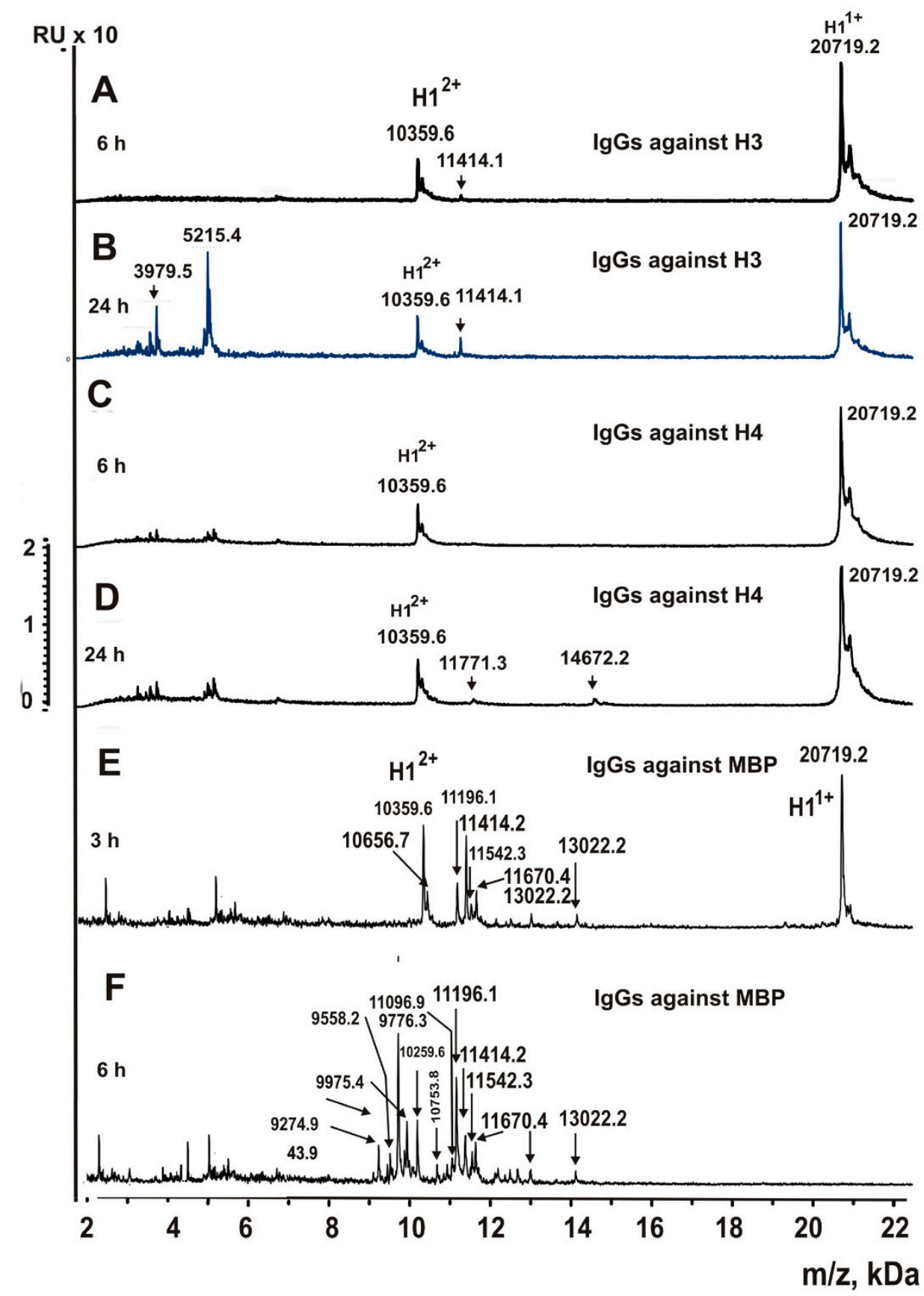

Figure 3. MALDI spectra (A-G) corresponding to $\mathrm{H} 1$ histone $(0.7 \mathrm{mg} / \mathrm{mL})$ hydrolysis over time (6-24 h), in the presence of IgGs $(0.04 \mathrm{mg} / \mathrm{mL})$ against H3 (A,B), H4 (C,D), and MBP (E,F).

As can be seen from Figure $4 \mathrm{~F}$ and Table 1, one of the $\mathrm{H} 1$ hydrolysis sites clusters in the case of anti-MBP antibodies, which contains 6 hydrolysis sites, located from P12 to $\mathrm{T} 22$ amino acid residues (AA). In this zone of the histone $\mathrm{H} 1$ protein sequence, there are no hydrolysis sites in the case of abzymes against five histones (Figure 4A-E, Table 1). It should be noted that the sites of histone $\mathrm{H} 1$ hydrolysis by antibodies against this histone are located mainly in two clusters: the first, V75-V104 (7 hydrolysis sites), and the second, A117-B142 (5 hydrolysis sites). 


\section{A 12 sites of $\mathrm{H} 1$ hydrolysis by IgGs against $\mathrm{H} 1$ histone}

1-Tenstsapaakpkrakaskkstdhpkysdmivaaiqaeknragssrqsiqkyikshykv-59

60-genadsqiklsikrlV:TtgvlkqtkgvgA $\downarrow$ Sgsf $\mathrm{R} \downarrow L \star A K \downarrow$ SdeP $\downarrow$ KkS $\downarrow$ Vaf-106

107-kkT $\downarrow$ KkeikkvA:TpkkaskpkkA:AsK $\star$ AptK $\star$ KpkatP:Vk-143

144-kakkklaatpkkakkpktvkakpvkaskpkkakpvkpkakssakragkkk-193

\section{B 9 sites of $\mathrm{H} 1$ hydrolysis by lgGs against $\mathrm{H} 2 \mathrm{~A}$ histone}

1-tenstsapaakpkrakaskkstdhpkysdmivaaiqaeknragssR:Qsiqkyikshykv-59

60-genadsqiklsikrlvttgvlkqtkgvgasgsf $\downarrow \downarrow L \downarrow$ AksdepkkS:V $\star$ Af-106

107-kkT:KkeikkvA $\downarrow$ TpkkaskpkK $\downarrow$ AaskA $\downarrow$ Ptkkpkatpvk-143

144-kakkklaatpkkakkpktvkakpvkaskpkkakpvkpkakssakragkkk-193

\section{7 sites of $\mathrm{H} 1$ hydrolysis by IgGs against H2B histone}

1-Tenstsapaakpkrakaskkstdhpkysdmivaaiqaeknragssrqsiqkyikshykv-59 60-genadsqiklsikrlvttgvlkQ:TkgvgasgsfR:LakS:DeP:Kksvaf-106 107 -kktkkeikkvatpkkaskpkK: A a s a ptkK: Pkatpvk-143 144-kakkklaatpkkA $\star$ Kkpktvkakpvkaskpkkakpvkpkakssakragkkk-193

\section{3 sites of $\mathrm{H} 1$ hydrolysis by IgGs against $\mathrm{H} 3$ histone}

1-Tenstsapaakpkrakaskkstdhpkysdmivaaiqaeknragssrqsiqkyikshykv-59 60-genadsqiklsikrlvttgvlkqtkgvgasgsfrlaksdepkksvaF:K-107 108-ktkkeikkvatpkkaskpkkaaskaptkkpkatpvk-143 144-kA $\star$ KkklaatpkkA $\downarrow$ Kkpktvkakpvkaskpkkakpvkpkakssakragkkk-193

\section{E 3 sites of $\mathrm{H} 1$ hydrolysis by IgGs against $\mathrm{H} 4$ histone}

1-Tenstsapaakpkrakaskkstdhpkysdmivaaiqaeknragssrqsiqkyikshykv-59 60-genadsqiklsikrlvttgvlkqtkgvgasgsfrlaksdepkksvaf-106

107-kkT:KkeikkvatpkkaskpkK:AaskaptkK:Pkatpvk-143 144-kakkklaatpkkakkpktvkakpvkaskpkkakpvkpkakssakragkkk-193

\section{F 17 sites of $\mathrm{H} 1$ hydrolysis by IgGs against MBP}

1-tenstsapaakP:KR $\downarrow A K \star A s K: K: S: T d h p k y s d m i v a a i q a e k n r a g s s r q s i q k-51$ Yikshykvgenadsqiklsikrlvttgvlkqtkgvgasgsfrlaksdep-100 101-P:KksV $\star A F \star K \downarrow K: T k k E \star I k K: V: A: T p K: K a s k p k k a a s K: A-132$ 133-ptkkpkatpvkkakkklaatpkkakkpktvkakpvkaskpkkakpvkpkakssakragkkk-193 
antibodies against $\mathrm{H} 3$ and $\mathrm{H} 4$ hydrolyze $\mathrm{H} 1$ histone very weakly. At the same time, in the zone of the first cluster from P12 to T22, the sites of H1 hydrolysis by these antibodies are completely absent. For antibodies against histones $\mathrm{H} 3$ and $\mathrm{H} 4$, only three $\mathrm{H} 1$ hydrolysis sites were reliably detected. Moreover, these sites are different, and they do not coincide with the sites of hydrolysis by antibodies against four other histones and against MBP, except for the site K127-A128, which is common for antibodies against H4, H2A, and H2B (Table 1).

Table 1. Sites of H1 histone hydrolysis by IgGs against hive histones and MBP.

\begin{tabular}{|c|c|c|c|c|c|}
\hline \multicolumn{6}{|c|}{ Type of IgGs } \\
\hline Anti-H1 & Anti-H2A & Anti-H2B & Anti-H3 & Anti-H4 & Anti-MBP \\
\hline- & - & - & - & - & P12-K13 * \\
\hline- & - & - & - & - & $14 R-15 A$ \\
\hline- & - & - & - & - & $16 \mathrm{~K}-17 \mathrm{~A} *$ \\
\hline- & - & - & - & - & K19-K20 \\
\hline- & - & - & - & - & K20-S21 \\
\hline- & - & - & - & - & S21-T22 \\
\hline- & R46-Q47 & - & - & - & - \\
\hline V75-T76 & - & - & - & - & - \\
\hline- & - & Q82-T83 & - & - & - \\
\hline R93-L94 & R93-L94* & R93-L94 & - & - & - \\
\hline R94-A95 & & - & - & - & - \\
\hline- & L94-A95 & - & - & - & - \\
\hline \multirow{2}{*}{ K96-S97 } & - & - & - & - & - \\
\hline & - & S97-D98 & - & - & - \\
\hline A88-S89 & - & & - & - & - \\
\hline P100-K101 & - & P100-K101 & & & P100-K101 \\
\hline S103-V104 & S103-V104 & - & - & - & - \\
\hline- & V104-A105 & - & - & - & V104-A105 \\
\hline- & - & - & F106-K107 & - & F106-K107 \\
\hline- & - & - & - & - & K107-K108 \\
\hline- & - & - & - & - & K108-T109 \\
\hline T109-K110 & T109-K110 & - & - & T109-K110 & - \\
\hline- & - & - & - & - & E112-I113 \\
\hline- & & & & & K115-V116 \\
\hline- & - & - & - & - & V116-A117 \\
\hline A117-T118 & A117-T118 & - & - & - & A117-T118 \\
\hline- & - & - & - & - & K120-K121 \\
\hline- & K127-A128 & K127-A128 & - & K127-A128 & - \\
\hline A128-A129 & - & - & - & - & - \\
\hline K131-A132 & - & - & - & - & K131-A132 \\
\hline- & A132-P133 & - & - & - & - \\
\hline \multirow[t]{2}{*}{ K135-K136 } & - & - & - & - & - \\
\hline & & K136-P137 & & K136-P137 & \\
\hline P141-V142 & - & - & - & - & - \\
\hline- & - & - & A145-K146 & - & - \\
\hline- & - & A156-K157 & A156-K157 & - & - \\
\hline
\end{tabular}

* Major hydrolysis sites are marked in bold, moderate in italics, and minor sites in normal. Missing hydrolysis sites are marked with a dash (-).

In general, the sites of H1 hydrolysis by antibodies against five histones differ significantly in their position in the protein sequence and in the efficiency of the hydrolysis. It should be noted that the major $\mathrm{H} 1$ hydrolysis sites for IgGs against various histones are also basically different: anti-H1 (R94-A95, K131-A132, K135-K136); anti-H2A (V104-A105); anti-H2B (A156-K157), anti-H3 (A145-K146). For anti-H4, a well-pronounced major site of hydrolysis was not revealed; for the first $3 \mathrm{~h}$, and only after $6 \mathrm{~h}$ of hydrolysis, a peak corresponding to the site T109-K110 appears, which may be marked as the average site. 


\section{Discussion}

As noted above, the complexation polyreactivity of antibodies is a widespread phenomenon [39-42]. Even to a certain extent, related compounds can form complexes with the same antibodies. This leads to the fact that during affinity, chromatography on a sorbent, not only antibodies against this antigen but also antibodies to compounds with structural elements of this antigen, can bind to the immobilized antigens [39-42]. However, the affinity of Abs for foreign molecules is usually significantly lower than for their own antigens. This leads to the fact that antibodies against foreign antigens are usually eluted during affinity chromatography when using $\mathrm{NaCl}$ at a concentration of up to $0.1-0.15 \mathrm{M}[1-6,32-34]$. Considering this, when isolating IgGs against five individual histones and MBP, we eluted antibodies nonspecifically bound to the immobilized six antigens using $0.2 \mathrm{M} \mathrm{NaCl}$. During further additional purification of the antibodies against histones and against MBP, they were additionally passed through alternative affinity sorbents. Eventually, antibody fractions were obtained against five individual histones and MBP.

As shown earlier in [31], the MS patients' antibody preparations used by us do not contain any admixtures of any canonical proteases. In addition, the same conclusion can be drawn based on the analysis of histone $\mathrm{H} 1$ hydrolysis sites with Abs against five histones and MBP. As is known, trypsin cleaves proteins after the residue of lysine (K) and arginine (R). The H1 sequence contains 67 sites for potential hydrolysis of this histone by trypsin. However, the number of sites of $\mathrm{H} 1$ hydrolysis by all used preparations of IgGs after $\mathrm{K}$ and $\mathrm{R}$ varies mainly from 0 (anti-H3 IgGs) to 2-3; only in the case of Abs against $\mathrm{H} 1$ and MBP, there are more: 4 and 7, respectively. Chymotrypsin breaks down proteins after aromatic amino acids $(\mathrm{F}, \mathrm{Y}, \mathrm{W})$. There are five potential such sites for hydrolysis of $\mathrm{H} 1$ histone by chymotrypsin. One site of hydrolysis after $\mathrm{F}$ was found in the case of anti-H3 (F106-K107; minor site) and anti-MBP (F106-107K; major site) IgGs (Table 1). In this regard, the data of [48] should be noted: when using a large number of monoclonal antibodies of patients with SLE, this study showed that their active centers could correspond to serine, thiol, or metal-dependent proteases. However, in contrast to canonical proteases, antibodies hydrolyze proteins mainly in their clusters that correspond to antigenic determinants [1-6,27-34]. It should be noted that, basically, the cleavage of $\mathrm{H1}$ by six antibody preparations occurs in clusters containing hydrolysis sites most often after neutral non-charged and nonaromatic AAs: A, V, L, and S (Figure 4, Table 1).

One of the unexpected and completely new results of this study is that antibodies not only against histone $\mathrm{H} 1$ but also against $\mathrm{H} 2 \mathrm{~A}, \mathrm{H} 2 \mathrm{~B}, \mathrm{H} 3$, and $\mathrm{H} 4$ are able to hydrolyze histone H1. The main evidence that the preparations of each of the antibodies to all individual histones and MBP do not contain at least noticeable impurities of IgGs against any of the other histones or MBP is that $\mathrm{H} 1$ hydrolysis sites for each of these preparations are significantly different (Figure 4, Table 1). In addition, the rate of hydrolysis of H1 histone by IgGs against $\mathrm{H} 2 \mathrm{~A}$ and $\mathrm{H} 2 \mathrm{~B}$ is comparable to that for antibodies against $\mathrm{H} 1$ histone, but is about 7-10 times lower for the abzymes against $\mathrm{H} 3$ and H4. Moreover, in the case of antibodies against H1 (12 sites), H2A (9 sites), and H2B (7 sites), a relatively large number of cleavage sites were found. Abzymes against $\mathrm{H} 3$ and $\mathrm{H} 4$ hydrolyze $\mathrm{H} 1$ histone only at three different sites. It is noteworthy that only a small number of hydrolysis sites by IgGs against different histones completely coincide (Table 1 ).

As shown previously by the example of hydrolysis of every of five individual histones with antibodies against each of these histones and against MBP from the blood of HIVinfected patients, the main reason for cross-catalysis may be the high level of homology of the sequences of MBP and histones [32-34]. Taking this into account, it seemed interesting to analyze the general homology between the protein sequence of $\mathrm{H} 1$ with four histones and MBP.

The complete identity of AAs between $\mathrm{H} 1$ and $\mathrm{H} 2 \mathrm{~A}$ (three different alignments) varies from $25.5-26.7 \%$ (average value $26.4 \pm 1.2 \%$ ), while similarity (identical together with non-identical amino acids but with highly similar physicochemical properties) varies from 54.7 to $49.7 \%$ (average value $52.4 \pm 2.5 \%$ ). Identity between $\mathrm{H} 1$ and $\mathrm{H} 2 \mathrm{~B}$ changes according 
to three different alignments changes, from 25.3 to $31.5 \%$ (average $29.2 \pm 3.4 \%$ ), and similarity from 50.5 to $55.4 \%$ (average value $53.5 \pm 2.7 \%$ ). For $\mathrm{H} 1$ and $\mathrm{H} 3$, the following homology characteristics were found: identity varies between $23.2-28.0 \%$ (average value $25.6 \pm 3.4 \%$ ), and similarity between $51.0-51.4 \%$ (average value $51.2 \pm 0.3 \%$ ). Approximately the same homology data was obtained for $\mathrm{H} 1$ and $\mathrm{H} 4$ histones: identity varied between $-27.3-31.2 \%$ (average $29.2 \pm 2.8 \%$ ), and similarity between $-48.6-50.0 \%$ (average value $49.3 \pm 1.0 \%$ ). The maximum coincidence of AAs (identity) is observed for H1 with H2B and H4 (29\%), while the similarity in $\mathrm{H} 1$ sequence with those for the other four histones is comparable $(49.3-53.5 \%)$. Thus, the homology of the protein sequences H2A, H2B, H3, and H4 with H1 is high and comparable.

An analysis of the homology of the complete sequences of MBP and five histones was carried out: for $\mathrm{H1}$, identity varied between $-25.4-28.4 \%(26.9 \pm 2.1 \%)$, and similarity between $48.8-52.8 \%$ ( $50.8 \pm 2.8 \%$ ); for $\mathrm{H} 2 \mathrm{~A}$, identity varied between $-25.0-26.8 \%$ $(25.9 \pm 1.3 \%)$, and similarity between $47.6-50.3 \%(49.0 \pm 1.9 \%)$; for $\mathrm{H} 2 \mathrm{~B}$, only one variant of identity was found: identity $-25.9 \%$ ) and similarity was $52.4 \%$ ). For $\mathrm{H} 3$, identity varied between $-22.8-25.3 \%(24.4 \pm 1.4 \%)$, and similarity between $44.3-47.6 \%(45.5 \pm 1.8 \%)$; for $\mathrm{H} 4$, identity varied between $-25.0-29.4 \%$ (27.2 \pm 3.1$)$, and similarity between 46.2-48.6 $(47.4 \pm 1.1 \%)$. The indices of the identity of the AAs of the protein sequence of MBP with those for five histones (24.4-27\%), as well as the similarity (45.5-52.4\%), are also very close, and almost do not differ from those for $\mathrm{H} 1$ and the four other histones. Therefore, these data could explain the possibility of $\mathrm{H} 1$ hydrolysis by antibodies against five histones and MBP (Figure 4, Table 1). Due to the high level of homology of the sequences of five histones and MBP, antibodies against these proteins are able not only to form complexes with H1, but also to hydrolyze this histone. In addition, all histones and MBP contain a large number of positively charged residues of lysine and arginine. Such AA residues are necessary for histones' interactions with negatively charged internucleoside phosphate groups of DNAs. At the same time, it has been shown that MBP is also capable of efficiently forming complexes with DNAs [49]. Thus, it is possible that a large number of positively charged AAs in all histones and MBPs can also make a significant contribution to the ability of antibodies against these proteins to form complexes with foreign histones.

\section{Conclusions}

In this article, we have first shown, on the example of IgGs from patients with multiple sclerosis, that IgGs against H2A, H2B, H3, H4, and myelin basic protein possess an ability similar to anti-H1 IgGs to form complexes with $\mathrm{H} 1$ histone, demonstrating polyreactivity in complexation. Moreover, an unexpected result was obtained. IgG-abzymes against $\mathrm{H} 2 \mathrm{~A}, \mathrm{H} 2 \mathrm{~B}, \mathrm{H} 3, \mathrm{H} 4$, and MBP possess catalytic cross-reactivity with anti-H1 antibodies, and all of these are capable of hydrolyzing histone H1. Evidence that the ability of IgGs against $\mathrm{H} 1, \mathrm{H} 2 \mathrm{~A}, \mathrm{H} 2 \mathrm{~B}, \mathrm{H} 3, \mathrm{H} 4$, and MBP to hydrolyze $\mathrm{H} 1$ histone is their own property follows from the fact that the sites of hydrolysis of $\mathrm{H} 1$ histone by different antibodies are individual for each IgG preparation, and differ in their location in the H1 protein molecule. Since histones constantly occur in human blood due to cell apoptosis, the existence of the enzymatic cross-reactivity of abzymes against histones and MBP can play a very negative role in MS pathogenesis.

Supplementary Materials: The following are available online at https://www.mdpi.com/article/ 10.3390/biom11081140/s1, Table S1: Several different medical characteristics of MS patients.

Author Contributions: Conceptualization, G.A.N. and P.S.D.; methodology, V.N.B. and S.V.B.; formal analysis, V.N.B. and G.A.N.; investigation, S.V.B. and P.S.D.; resources, G.A.N.; data curation, G.A.N. and V.N.B.; writing-original draft preparation, G.A.N. and V.N.B.; writing-review and editing, G.A.N.; project administration, G.A.N.; funding acquisition, G.A.N. and P.S.D. All authors have read and agreed to the published version of the manuscript. 
Funding: This research was endorsed by a grant of the Russian Science Foundation, 19-15-00145 and the Russian State-funded budget project of ICBFM SB RAS 2013-2020 № AAAA-A17-117020210023-1 (salary of authors).

Institutional Review Board Statement: The protocol of blood sampling was confirmed by the local human ethics committee (Novosibirsk State Medical University, Novosibirsk, Russia; number 105HIV; 07. 2010). This ethics committee supported this study based on the guidelines of the Helsinki ethics committee.

Informed Consent Statement: All patients made a written agreement to donate blood for scientific purposes.

Data Availability Statement: The data that supports the findings of this study are available within the article and its supplementary material.

Conflicts of Interest: The coauthors have no competing financial interests.

\begin{abstract}
Abbreviations
AA: amino acid; Ab, antibody; ABZ, abzyme; HIV-1, human immunodeficiency virus type 1; MALDI-TOF, matrix-assisted laser desorption/ionization time-of-flight mass spectrometry; MBP, myelin basic protein; SDS-PAGE, sodium dodecyl sulfate-polyacrylamide gel electrophoresis; MS, multiple sclerosis; SDS-PAGE, sodium dodecyl sulfate-polyacrylamide gel electrophoresis; SLE, systemic lupus erythematosus.
\end{abstract}

\title{
References
}

1. David, B.S. Catalytic Antibodies; Keinan, E., Ed.; Wiley-VCH Verlag GmbH and Co. KgaA: Weinheim, Germany, $2005 ;$ pp. 1-586.

2. Nevinsky, G.A.; Buneva, V.N. Natural catalytic antibodies-abzymes. In Catalytic Antibodies; Keinan, E., Ed.; VCH-Wiley Press: Weinheim, Germany, 2005; pp. 505-569.

3. Nevinsky, G.A. Natural catalytic antibodies in norm and in autoimmune diseases. In Autoimmune Diseases: Symptoms, Diagnosis and Treatment; Brenner, K.J., Ed.; Nova Science Publishers Inc.: New York, NY, USA, 2010; pp. 1-107.

4. Nevinsky, G.A. Natural catalytic antibodies in norm and in HIV-infected patients. In Understanding HIV/AIDS Management and Care-Pandemic Approaches the 21st Century; Kasenga, F.H., Ed.; InTech: Rijeka, Croatia, 2011; pp. 151-192.

5. Nevinsky, G.A. Autoimmune processes in multiple sclerosis: Production of harmful catalytic antibodies associated with significant changes in the hematopoietic stem cell differentiation and proliferation. In Multiple Sclerosis; Conzalez-Quevedo, A., Ed.; InTech: Rijeka, Croatia, 2016; pp. 100-147.

6. Nevinsky, G.A. Catalytic antibodies in norm and systemic lupus erythematosus. In Lupus; Khan, W.A., Ed.; InTech: Rijeka, Croatia, 2017; pp. 41-101.

7. Jerne, N.K. Towards a network theory of the immune system. Ann. Immunol. 1974, 125, 373-398.

8. Shuster, A.M.; Gololobov, G.V.; Kvashuk, O.A.; Bogomolova, A.E.; Smirnov, I.V.; Gabibov, A.G. DNA hydrolyzing autoantibodies. Science 1992, 256, 665-667. [CrossRef]

9. Andrievskaya, O.A.; Buneva, V.N.; Naumov, V.A.; Nevinsky, G.A. Catalytic heterogenity of polyclonal RNA-hydrolyzing IgM from sera of patients with lupus erythematosus. Med. Sci. Monit. 2000, 6, 460-470.

10. Andrievskaya, O.A.; Buneva, V.N.; Baranovskii, A.G.; Gal'vita, A.V.; Benzo, E.S.; Naumov, V.A.; Nevinsky, G.A. Catalytic diversity of polyclonal RNA-hydrolyzing IgG antibodies from the sera of patients with systemic lupus erythematosus. Immunol. Lett. 2002, 81, 191-198. [CrossRef]

11. Baranovskii, A.G.; Kanyshkova, T.G.; Mogelnitskii, A.S.; Naumov, V.A.; Buneva, V.N.; Gusev, E.I.; Boiko, A.N.; Zargarova, T.A.; Favorova, O.O.; Nevinsky, G.A. Polyclonal antibodies from blood and cerebrospinal fluid of patients with multiple sclerosis effectively hydrolyze DNA and RNA. Biochemistry 1998, 63, 1239-1248. [PubMed]

12. Baranovsky, A.G.; Matushin, V.G.; Vlassov, A.V.; Zabara, V.G.; Naumov, V.A.; Giege, R.; Buneva, V.N.; Nevinsky, G.A. DNAand RNA-hydrolyzing antibodies from the blood of patients with various forms of viral hepatitis. Biochem. N. Y. Engl. Transl. Biokhimiya 1997, 62, 1358-1366.

13. Savel'ev, A.N.; Eneyskaya, E.V.; Shabalin, K.A.; Filatov, M.V.; Neustroev, K.N. Antibodies with amylolytic activity. Protein Peptide Lett. 1999, 6, 179-181.

14. Savel'ev, A.N.; Kanyshkova, T.G.; Kulminskaya, A.A.; Buneva, V.N.; Eneyskaya, E.V.; Filatov, M.V.; Nevinsky, G.A.; Neustroev, K.N. Amylolytic activity of IgG and sIgA immunoglobulins from human milk. Clin. Chim. Acta 2001, 314, 141-152. [CrossRef]

15. Neustoev, K.N.; Ivanen, D.R.; Kulminskaya, A.A.; Brumer, I.H.; Saveliev, A.N.; Nevinsky, G.A. Amylolytic activity and catalytic properties of IgM and IgG antibodies from patients with systemic lupus erythematosus. Hum. Antibodies 2003, 12, 31-34.

16. Paul, S.; Volle, D.J.; Beach, C.M.; Johnson, D.R.; Powell, M.J.; Massey, R.J. Catalytic hydrolysis of vasoactive intestinal peptide by human autoantibody. Science 1989, 244, 1158-1162. [CrossRef] [PubMed] 
17. Li, L.; Paul, S.; Tyutyulkova, S.; Kazatchkine, M.D.; Kaveri, S. Catalytic activity of anti-thyroglobulin antibodies. J. Immunol. 1995, 154, 3328-3332.

18. Kalaga, R.; Li, L.; O’Dell, J.R.; Paul, S. Unexpected presence of polyreactive catalytic antibodies in IgG from unimmunized donors and decreased levels in rheumatoid arthritis. J. Immunol. 1995, 155, 2695-2702.

19. Thiagarajan, P.; Dannenbring, R.; Matsuura, K.; Tramontane, A.; Gololobov, G.; Paul, S. Monoclonal antibody light chain with prothrombinase activity. Biochemistry 2000, 39, 6459-6465. [CrossRef]

20. Lacroix-Desmazes, S.; Moreau, A.; Sooryanarayana; Bonnemain, C.; Stieltjes, N.; Pashov, A.; Sultan, Y.; Hoebeke, J.M.; Kazatchkine, D.; Kaveri, S.V. Catalytic activity of antibodies against factor VIII in patients with hemophilia A. Nat. Med. 1999, 5, 1044-1047. [CrossRef] [PubMed]

21. Polosukhina, D.I.; Kanyshkova, T.G.; Doronin, B.M.; Tyshkevich, O.B.; Buneva, V.N.; Boiko, A.N.; Gusev, E.I.; Favorova, O.O.; Nevinsky, G.A. Hydrolysis of myelin basic protein by polyclonal catalytic IgGs from the sera of patients with multiple sclerosis. J. Cell Mol. Med. 2004, 8, 359-368. [CrossRef]

22. Polosukhina, D.I.; Kanyshkova, T.G.; Doronin, B.M.; Tyshkevich, O.B.; Buneva, V.N.; Boiko, A.N.; Gusev, E.I.; Nevinsky, G.A.; Favorova, O.O. Metal-dependent hydrolysis of myelin basic protein by IgGs from the sera of patients with multiple sclerosis. Immunol. Lett. 2006, 103, 75-81. [CrossRef] [PubMed]

23. Baranova, S.V.; Buneva, V.N.; Kharitonova, M.A.; Sizyakina, L.P.; Calmels, C.; Andreola, M.L.; Parissi, V.; Nevinsky, G.A. HIV-1 integrase-hydrolyzing antibodies from sera of HIV-infected patients. Biochimie 2009, 91, 1081-1086. [CrossRef] [PubMed]

24. Paul, S.; Planque, S.A.; Nishiyama, Y.; Hanson, C.V.; Massey, R.J. Nature and nurture of catalytic antibodies. Adv. Exp. Med. Biol. 2012, 750, 56-75.

25. Planque, S.A.; Nishiyama, Y.; Hara, M.; Sonoda, S.; Murphy, S.K.; Watanabe, K.; Mitsuda, Y.; Brown, E.L.; Massey, R.J.; Primmer, S.R.; et al. Physiological IgM class catalytic antibodies selective for transthyretin amyloid. J. Biol. Chem. 2014, 289, 13243-13258. [CrossRef] [PubMed]

26. Chen, R.; Kang, R.; Fan, X.-G.; Tang, D. Release and activity of histone in diseases. Cell Death Dis. 2014, 5, e1370. [CrossRef] [PubMed]

27. Baranova, S.V.; Buneva, V.N.; Nevinsky, G.A. Antibodies from the sera of HIV-infected patients efficiently hydrolyze all human histones. J. Mol. Recognit. 2016, 29, 346-362. [CrossRef]

28. Baranova, S.V.; Dmitrienok, P.S.; Ivanisenko, N.V.; Buneva, V.N.; Nevinsky, G.A. Antibodies to H1 histone from the sera of HIV-infected patients recognize and catalyze site-specific degradation of this histone. J. Mol. Recognit. 2017, 30, e2588. [CrossRef]

29. Baranova, S.V.; Dmitrienok, P.S.; Ivanisenko, N.V.; Buneva, V.N.; Nevinsky, G.A. Antibodies to H2a and H2b histones from the sera of HIV-infected patients catalyze site-specific degradation of these histones. Mol. Biosyst. 2017, 13, 1090-1101. [CrossRef] [PubMed]

30. Baranova, S.V.; Dmitrenok, P.S.; Zubkova, A.D.; Ivanisenko, N.V.; Odintsova, E.S.; Buneva, V.N.; Nevinsky, G.A. Antibodies against $\mathrm{H} 3$ and $\mathrm{H} 4$ histones from the sera of HIV-infected patients catalyze site-specific degradation of these histones. J. Mol. Recognit. 2018, 31, e2703. [CrossRef] [PubMed]

31. Baranova, S.V.; Mikheeva, E.V.; Buneva, V.N.; Nevinsky, G.A. Antibodies from the Sera of Multiple Sclerosis Patients Efficiently Hydrolyze Five Histones. Biomolecules 2019, 9, 741. [CrossRef] [PubMed]

32. Baranova, S.V.; Dmitrienok, P.S.; Buneva, V.N.; Nevinsky, G.A. Autoantibodies in HIV-infected patients: Cross site-specific hydrolysis of $\mathrm{H} 1$ histone and myelin basic protein. Biofactors 2019, 45, 211-222. [CrossRef]

33. Baranova, S.V.; Dmitrienok, P.S.; Buneva, V.N.; Nevinsky, G.A. HIV-Infected Patients: Cross Site-Specific Hydrolysis of H2a and H2b Histones and Myelin Basic Protein with Antibodies against These Three Proteins. Biomolecules 2020, $10,1501$. [CrossRef] [PubMed]

34. Baranova, S.V.; Dmitrienok, P.S.; Buneva, V.N.; Sedykh, S.E.; Nevinsky, G.A. HIV-Infected Patients: Cross Site-Specific Hydrolysis of H3 and H4 Histones and Myelin Basic Protein with Antibodies against These Three Proteins. Molecules 2021, 26, 316. [CrossRef]

35. Bezuglova, A.V.; Konenkova, L.P.; Doronin, B.M.; Buneva, V.N.; Nevinsky, G.A. Affinity and catalytic heterogeneity and metaldependence of polyclonal myelin basic protein-hydrolyzing IgGs from sera of patients with systemic lupus erythematosus. J. Mol. Recognit. 2011, 24, 960-974. [CrossRef] [PubMed]

36. Parshukova, D.L.; Smirnova, P.; Ermakov, E.A.; Bokhan, N.A.; Semke, A.V.; Ivanova, S.A.; Buneva, V.N.; Nevinsky, G.A. Autoimmunity and immune system dysregulation in schizophrenia: IgGs from sera of patients hydrolyze myelin basic protein. J. Mol. Recognit. 2019, 32, e2759. [CrossRef]

37. Aulova, K.S.; Toporkova, L.B.; Lopatnikova, J.A.; Alshevskaya, A.A.; Sedykh, S.E.; Buneva, V.N.; Budde, T.; Meuth, S.G.; Popova, N.A.; Orlovskaya, I.A.; et al. Changes in cell differentiation and proliferation lead to production of abzymes in EAE mice treated with DNA-Histone complexes. J. Cell Mol. Med. 2018, 22, 5816-5832. [CrossRef] [PubMed]

38. Founel, S.; Muller, S. Antinucleosome antibodies and T-cell response in systemic lupus erythematosus. Ann. Med. Interne 2002, $153,513-519$.

39. Zhou, Z.H.; Tzioufas, A.G.; Notkins, A.L. Properties and function of polyreactive antibodies and polyreactive antigen-binding B cells. J. Autoimmun. 2007, 29, 219-228. [CrossRef] [PubMed]

40. James, L.C.; Roversi, P.; Tawfik, D.S. Antibody multispecificity mediated by conformational diversity. Science 2003, 299, 1362-1367. [CrossRef] [PubMed]

41. James, L.C.; Tawfik, D.S. Conformational diversity and protein evolution-a 60-year-old hypothesis revisited. Trends Biochem. Sci. 2003, 28, 361-368. [CrossRef] 
42. James, L.C.; Tawfik, D.S. The specificity of cross-reactivity: Promiscuous antibody binding involves specific hydrogen bonds rather than nonspecific hydrophobic stickiness. Protein Sci. 2003, 12, 2183-2193. [CrossRef] [PubMed]

43. Nevinsky, G.A. Structural, thermodynamic, and kinetic basis of DNA- and RNA-dependent enzymes functioning: Important role of weak nonspecific additive interactions between enzymes and long nucleic acids for their recognition and transformation. In Protein Structures: Kaleidoscope of Structural Properties and Functions; Uversky, V.N., Ed.; Research Signpost: Kerala, India, 2003; pp. 133-222.

44. Nevinsky, G.A. Structural, thermodynamic, and kinetic basis for the activities of some nucleic acid repair enzymes. J. Mol. Recognit. 2011, 24, 656-677. [CrossRef] [PubMed]

45. Nevinsky, G.A. How Enzymes, Proteins, and Antibodies Recognize Extended DNAs, General Regularities. Int. J. Mol. Sci. 2021, 22, 1369. [CrossRef] [PubMed]

46. McDonald, W.I.; Compston, A.; Edan, G.; Goodkin, D.; Hartung, H.P.; Lublin, F.D.; McFarland, H.F.; Paty, D.W.; Polman, C.H.; Reingold, S.C.; et al. Recommended diagnostic criteria for multiple sclerosis: Guidelines from the International Panel on the Diagnosis of Multiple Sclerosis. Ann. Neurol. 2001, 50, 121-127. [CrossRef]

47. Kurtzke, J.F. Rating neurological impairment in multiple sclerosis: An expanded disability scale (EDSS). Neurology 1983, 33, 1444-1452. [CrossRef]

48. Timofeeva, A.M.; Buneva, V.N.; Nevinsky, G.A. Systemic lupus erythematosus: Molecular cloning and analysis of 22 individual recombinant monoclonal kappa light chains specifically hydrolyzing human myelin basic protein. J. Mol. Recognit. 2015, 28, 614-627. [CrossRef] [PubMed]

49. Krasitskaya, V.V.; Chaukina, V.V.; Abroskina, M.V.; Vorobyeva, M.A.; Ilminskaya, A.A.; Kabilov, M.R.; Prokopenko, S.V.; Nevinsky, G.A.; Venyaminova, A.G.; Frank, L.A. Bioluminescent aptamer-based sandwich-type assay of anti-myelin basic protein autoantibodies associated with multiple sclerosis. Anal. Chim. Acta 2019, 1064, 112-118. [CrossRef] [PubMed] 